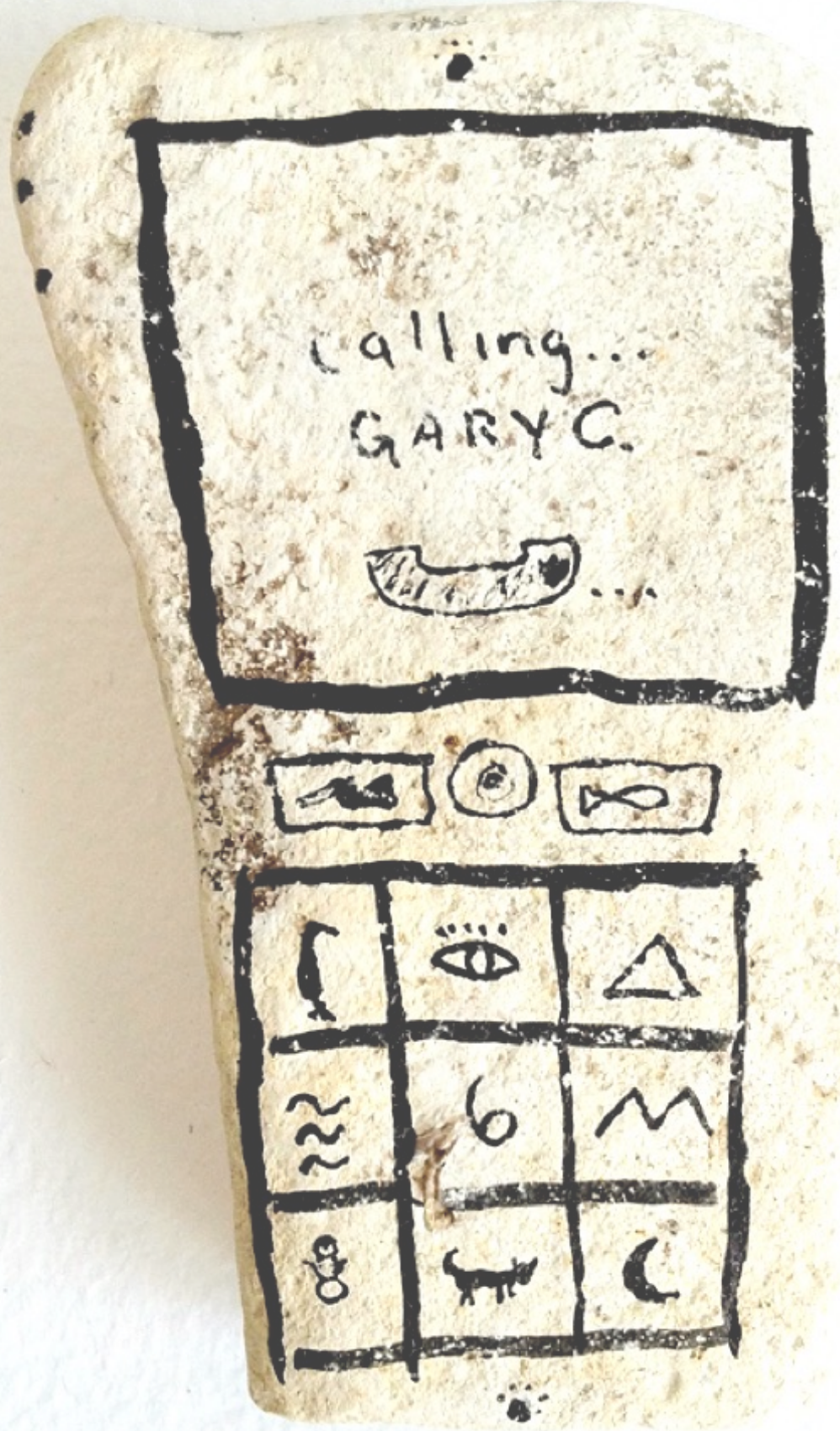

SUPERCARGO by Peter Moosgaard, essay by Martin Ochsenhofer. 


\section{'SUPERCARGO', the Art of Peter Moosgaard}

\section{Martin Ochsenhofer}

Viennese media artist Peter Moosgaard's work, 'Supercargo', can be understood as an experimental attempt to deal with recent, social and cultural phenomena that occur in our western capitalist consumer society. Motivated by the interest in the permanently changing conditions and the vast level of consumer choices created by the market conditioned by the capitalist mode of increasing profits, Peter Moosgaard's art serves as a tool for critical analysis. The work itself is not a simple critique of mechanisms that we are subjected to on a daily basis, but rather a playful approach that looks behind the scenes of the structures of consumerism and the role of the consumer object itself. Questions like value creation, identification through objects and desire, form the core of his work. In what follows, I will build on those ideas and provide them with a theoretical foundation or rather a superstructure, based on my interpretation of Peter Moosgaard's work.

The modern western world as we understand it and as we are thrown into it comes with special tasks that sometimes make our life difficult for us. Among other things, it is getting more difficult nowadays to make consumer decisions, because there is an overwhelming amount of options out there on top of the complexity of the act of buying a commodity has rapidly increased since the rise of capitalism in the West. According to Zygmunt Baumann consumerism is: 'a type of social arrangement that results from recycling mundane, permanent and so to speak "regime-neutral" human wants, desires and longings into the principal propelling and operating force of society, a force that coordinates systemic reproduction, social integration, social stratification and the formation of human individuals' (Bauman 2007, 28). Consumerism has become a tool to materialise order in our social life, with the focus on essential human needs. The need to experience belonging to a group and the need to feel like a differentiated individual are two distinct and fundamental motives that shape human behaviour (Baumeister \& Leary, 1995). On one hand assimilation and on the other the urge for differentiation, both are concurrent driving forces that demand a coping mechanism that can satisfy both needs simultaneously. The purpose of such a mechanism is to allow people to identify with a social group that is inclusive enough to alleviate social isolation and, at the same time, exclusive enough to provide a sense of distinctiveness (Moon, Sung 2015: 16). This desire for individuality in a capitalist consumerist society can lead us to choose from a variety of commodities that promise to provide us with individual expression and identification. Advertising is using this human desire for both belonging and distinctiveness as a strategy for marketing and sales. It appears that this is working out, especially if we look at the profit margins of successful companies such as Apple, an iconic example of a company that has managed to provide both for its consumers: a sense of distinctiveness and a sense of belonging to a community of those privileged. Through such advertising strategies, a desire to consume the latest things in order to maintain our individuality and reproduce social relations is successfully created.

In a capitalist consumer society flooded by mass produced goods, the need for something special and authentic grows. In a system in which the increase in profit is the 
driving element, the production of consumer goods becomes standardised, directed at efficiency. This fact can lead to a dilemma: we want to buy something unique, that no one else has, but such an object becomes very rare. Wirsching Andreas, in his work about individuality in a modern mass society, argues that "the "standardisation of products" automatically entailed the standardisation of "needs" (Wirsching 2011, 4). Therefore, we can conclude that individuality expressed in consumer goods is also based on forces created by the market rather than on any intrinsic choice. The mechanisms at work when we believe that a specific product is fulfilling all our needs to enable us to fit into a specific group and distinguish us from the rest, are not easy to understand. Josef Heath, a philosophy professor at the University of Toronto, argues that 'every consumer desire we have is a product of cultural environment and all culture is, in an important sense, artificial' (Heath 2001: 6). In order to understand the whole concept of consumerism, we have to open our horizon and thread into subtle levels beyond looking at the pragmatic and utilitarian characteristics of a commodity such as, the function and purpose it serves. When we look at the art world, for instance, a commodity can easily become an object of high value because of the context in which it is set. This object is then endowed with an aura of a deeper intellectual realm, something that shows on the market the price and the increase of its value. In order to analyse the strategies we use on a daily basis to make consumer decisions, we can invoke the concept of fetishism from Karl Marx. This may give us the chance to question the very habits of consumerism that often appear to be irrational. To create a distinction between us and the others, commodities can serve as a symbol which differentiates us from the rest, something that can serve as a source of fetishisation of objects. Marx in his Capital calls this 'the fetishism of commodities' (Marx, 1977), by which he meant that commodities take on a life of their own which depends not on their use value, but rather on a fictitious exchange value which, in capitalist societies, soars so high above the use value that commodities assume a 'mystical character' (Wirsching 2011,3). The object itself can, therefore, be seen as a multidimensional entity, where the use value is just one element of it. When we look at modern technologies such as the latest iPhone, most of us do not understand the technology and what makes this device special and gives it its distinctiveness. Our choice to purchase exactly this product is instead based on an ideology we associate with it where taste plays an elementary role in this decisionmaking process. Bourdieu argues, in his classic work Distinction, that 'taste' is a social construction which is constructed out of a sanctioned, and essentially non-aesthetic distinction between 'good taste' and 'bad taste' (Bourdieu, 1984). One of the ways to express such distinction is to stigmatise the consumption choices of out-group members as morally or intellectually inferior, or deficient in other ways. From this perspective, then, the idea that 'consumerism' reflects an inferior set of values must be treated with the utmost suspicion (Heath 2001: 7). This point of view opens up a new field for further investigation to be able to understand the complexity of the value creation process.

To study and analyse this 'mystical character' of commodities, Peter Moosgaard uses his art as an experimental tool for understanding and questioning the mechanisms of consumerism with its inherent forces. His artistic approach is based on a cult found in Melanesia, the so-called cargo-cult, in which indigenous people in Melanesia, after the colonial invasion of the South Pacific region, mocked up airstrips, planes and technologies such as radio devices, looking for western manufactured industrialised goods to come back to them in the future. This could be seen as an elaborate 
misunderstanding of cause and effect, whereby locals were not familiar with the technologies used by the arriving people (Lawrence 1989). However, if we look more closely, even if the act of mocking up things we do not know and placing hope and faith in them can be seen as something irrational and people may laugh about it, we, if we reflect upon our consumer habits, do exactly the same on a daily basis. We infuse commodities with hope and faith, in order to create our individual position in society. Consumerism thus also inherently follows the ritualistic path.

According to Holmquist, it is the 'performing of imitative rituals without an understanding of the underlying cause and effect that gives a cargo cult its metaphorical power' (Holmquist 2005, 49). To create mock ups of commodities without function sharpens our perspective on the objects in themselves. The fact that Peter Moosgaard uses easily accessible materials, such as wooden branches, stones and even waste, enables a broad range of people to playfully engage with them, and move out of their ordinary perspectives. The object then exists as a pure form of itself, without the earlier discussed aspects of value creating elements. It is precisely from this angle that we can develop a differentiated view about the many spheres by which consumer objects are surrounded and thus reflect on our individual habits as consumers that are often carried out unconsciously. Hence, Moosgaard's artworks allow us to grasp the holistic identity of the object and provide us with insight into the processes that are not visible at the first glimpse.

Bauman, Zygmunt. 2007. Consuming Life. Cambridge: Polity Press.

Baumeister, R. F., \& Leary, M. R. 1995. 'The need to belong: Desire for interpersonal attachments as a fundamental human motivation', Psychological Bulletin, 117: 497-529.

Bourdieu, Pierre. 1984. Distinction: a Social Critique of the Fudgement of Taste, London: Routledge \& Kegan Paul.

Heath, Joseph. 2001. 'The structure of hip consumerism', Philosophy \&̊ Social Criticism, 27(6): 1-17.

Holmquist, L. E. 2005. 'Prototyping: generating ideas or cargo cult designs?', Interactions 12(2): 48-54.

Lawrence, P. 1989. Road Belong Cargo: A Study of the Cargo Movement in the Southern Madang District, New Guinea: Waveland Press.

Marx, K. 1977. Capital: A Crtique of Political Economy, Volume 1, New York: Vintage.

Moon, J.H. \& Sung, Y. 2015. 'Individuality within the group: Testing the optimal distinctiveness principle through brand consumption', Social Behavior and Personality, 43(1): 15-26.

Wirsching, Andreas. 2011. 'From Work to Consumption. Transatlantic Visions of Individuality in Modern Mass Society', Contemporary European History, 20(1): $1-26$. 